\title{
Treatment of strongly acidic wastewater with high arsenic concentrations by ferrous sulfide (FeS): Inhibitive effects of $\mathrm{S}(0)$-enriched surfaces
}

\author{
Ruiping Liu ${ }^{\mathrm{a}}$, Zhongchao Yang ${ }^{\mathrm{a}}$, Ziliang $\mathrm{He}^{\mathrm{a}, \mathrm{b}}$, Liyuan $\mathrm{Wu}^{\mathrm{a}}$, Chengzhi $\mathrm{Hu}^{\mathrm{a}, *}$, Wenzhu $\mathrm{Wu}^{\mathrm{c}}$, Jiuhui $\mathrm{Qu}^{\mathrm{a}}$ \\ ${ }^{a}$ Key Laboratory of Drinking Water Science and Technology, Research Center for Eco-Environmental Sciences, Chinese Academy of Sciences, Beijing 100085, China \\ ${ }^{\mathrm{b}}$ School of Civil and Transportation Engineering, Hebei University of Technology, Tianjin 300400, China \\ ${ }^{\mathrm{c}}$ Key Laboratory of Pesticide Environmental Assessment and Pollution Control, Nanjing Institute of Environmental Science, Ministry of Environmental Protection of China, \\ Nanjing 210042, China
}

\section{H I G H L I G H T S}

- FeS shows higher removal efficiency towards As(III) than As(V).

- In acidic solution FeS dissolve to $\mathrm{S}(-\mathrm{II})$ for $\mathrm{As}(\mathrm{V})$ reduction and $\mathrm{As}_{2} \mathrm{~S}_{3}$ formation.

- $\mathrm{S}(-\mathrm{II})$ react with $\mathrm{As}(\mathrm{V})$ to form $\mathrm{S}(0)$ rich surface on FeS and inhibit As removal.

- S(II)-rich surface inhibit FeS dissolution and arsenic removal. - $\mathrm{As}(\mathrm{V})$ reduction to $\mathrm{As}(\mathrm{III})$ by dosing $\mathrm{Na}_{2} \mathrm{~S}$ prior to $\mathrm{FeS}$ improve $\mathrm{As}(\mathrm{V})$ removal.

\section{A R T I C L E I N F O}

\section{Article history:}

Received 1 March 2016

Received in revised form 24 May 2016

Accepted 25 May 2016

Available online 26 May 2016

\section{Keywords:}

High-arsenic wastewater

Acidity

FeS

$\mathrm{As}_{2} \mathrm{~S}_{3}$

$\mathrm{S}(0)$-enriched surfaces

\section{G R A P H I C A L A B S T R A C T}

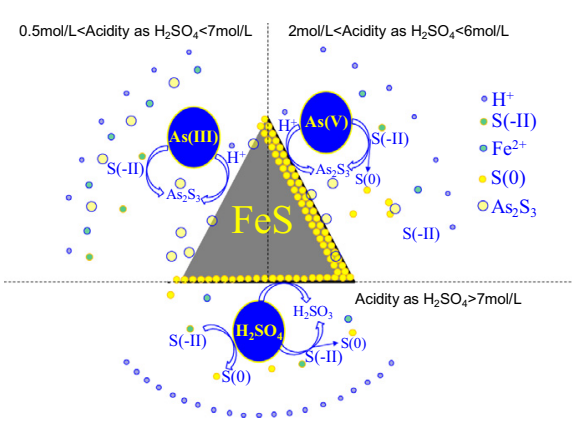

\section{A B S T R A C T}

The utilization of arsenopyrite (FeAsS), the As ore mineral, produces strongly acidic wastewater with extremely high arsenic (As) concentrations. This study investigates the feasibility of using ferrous sulfide (FeS) as a sulfide $[\mathrm{S}(-\mathrm{II})]$ source to treat strongly acidic wastewater with high concentrations of arsenite [As(III)] and arsenate [As(V)]. The removal of As(III) by FeS was nearly 30\% higher than that of As(V), and higher acidity and elevated FeS doses benefited their removal. At extremely high acidity of above $7 \mathrm{~mol} / \mathrm{L}$ as $\mathrm{H}_{2} \mathrm{SO}_{4}$, the consumption of $\mathrm{S}(-\mathrm{II})$ by $\mathrm{H}_{2} \mathrm{SO}_{4}$ inhibited As removal. At lower acidity of below $2 \mathrm{~mol} / \mathrm{L}$ as $\mathrm{H}_{2} \mathrm{SO}_{4}$, elevated FeS doses up to 4 times the theoretical dose could achieve good As removal. SEM/EDS and XPS analysis indicated the formation of $\mathrm{As}_{2} \mathrm{~S}_{3}$ precipitates, and sulfur $[\mathrm{S}(0)]$ also formed in the $\mathrm{As}(\mathrm{V})$ removing system. The tiny and negatively-charged $S(0)$ particles tend to coat the FeS surface. The $S(0)$ enriched surface acts as a barrier to inhibit S(-II) detachment and As(V) penetration and inhibits $\mathrm{As}(\mathrm{V})$ removal thereafter. The reduction of $\mathrm{As}(\mathrm{V})$ to $\mathrm{As}(\mathrm{III})$ by $\mathrm{Na}_{2} \mathrm{~S}$, prior to dosing with FeS, is preferred to achieve rapid and favorable As(V) removal. The low-cost FeS provides available Fe(II) and S(-II) for As removal, and is practically valuable to treat acidic high-As wastewater.

(C) 2016 Elsevier B.V. All rights reserved.

\footnotetext{
* Corresponding author.

E-mail address: czhu@rcees.ac.cn (C. Hu).
}

\section{Introduction}

Arsenic (As) is widely distributed and occurs in more than 200 minerals [1]. Arsenopyrite, FeAsS, is the most abundant As ore mineral in the Earth's crust, and is frequently associated with 
the minerals pyrite and arsenian ('arsenic-rich') pyrite $\left(\mathrm{Fe}(\mathrm{S}, \mathrm{As})_{2}\right)$. Pyrite, with the associated FeAsS, has been widely used as a raw material for the sulfuric acid manufacturing industry, and the As content of above $0.05 \%$ within raw material may exert arsenic pollution problems involve in. The mining and smelting industries using As ore minerals sometimes produce wastewater with extremely high As concentrations, from several thousand to tens of thousands $\mathrm{mg} / \mathrm{L}$. Additionally, these wastewaters are usually strongly acidic and named as acidic mining drainage (AMD), and they are usually continuously reclaimed and recirculated due to the difficulty to achieve the discharging standard. This strategy concentrates the acid greatly and the percentage concentrations of acid may be even as high as 1-30 percent. The AMD with extremely high acid concentrations of over $10 \%$ may be relatively uncommon; however, it does occur in some factories. The discharge of these AMD creates great risks to the environment and is strictly prohibited, and the permitted As concentration for discharge is below $0.5 \mathrm{mg} / \mathrm{L}$ in China [2]. To avoid As pollution in the environment, the As-related industries must be well monitored to avoid either deliberate or unexpected discharge of point and non-point AMD. The development of highly-efficient, relatively low cost, and easy-to-handle technologies to treat these AMD is crucial for the control of arsenic pollution in the environment.

The abundant association of As with the mineral pyrite in Earth's crust suggests the feasibility of using pyrite and ferrous sulfide (FeS) for As removal. Zouboulis et al. (1993) first proposed the use of pyrite fines as an adsorbents for the removal of arsenite [As (III)] and arsenate $[\mathrm{As}(\mathrm{V})][3]$. In the uptake of $\mathrm{As}(\mathrm{V})$ by pristine pyrite, $\mathrm{As}(\mathrm{V})$ is first reduced to $\mathrm{As}(\mathrm{III})$ and then is incorporated into the solid phase; however, on surface-oxidized pyrite, $\mathrm{As}(\mathrm{V})$ reduction rarely occurs [4]. The products formed on pyrite surfaces are complicated. The formation of $\mathrm{As}_{2} \mathrm{~S}_{3}$ or $\mathrm{As}_{4} \mathrm{~S}_{4}$ surface phases has been demonstrated in the uptake of $\mathrm{As}(\mathrm{III})$ and $\mathrm{As}(\mathrm{V})$ by synthetic pyrite [5], and the formation of outer-sphere surface complexes between $\mathrm{As}(\mathrm{V}) / \mathrm{As}(\mathrm{III})$ and mackinawite and pyrite is also reported [6]. Additionally, $\mathrm{pH}$ impacts the species of products formed between $\mathrm{As}(\mathrm{III})$ and nano- $\mathrm{FeS}_{\mathrm{m}}$ and the removal efficiency of As (III) thereafter [7]. Furthermore, FeS may be coated on quartz sand and be used as a adsorbent for flow-through reactors such as permeable reactive barriers [8]. The in situ coating of Fe-sulfide onto quartz sand by alternative injection of $\mathrm{Fe}(\mathrm{II}), \mathrm{O}_{2}$-free water and $\mathrm{S}^{2-}$ achieves good arsenic removal efficiency, and beside its direct uptake by Fe-sulfide coating, the surface complexation between As (III) and Fe oxides/hydroxides and the As(III) precipitation also involves in [9]. These studies mainly focus on the adsorption of arsenic; however, studies focusing on the treatment of AMD by precipitation are rare, to the best of our knowledge.

In strongly acidic solution, FeS may dissolve into $\mathrm{Fe}^{2+}$ and sulfide $\left(\mathrm{S}^{2-}\right)$ (Eq. (1)), and $\mathrm{S}^{2-}$ tends to transform into $\mathrm{HS}^{-}$and $\mathrm{H}_{2} \mathrm{~S}$ in acidic solution (Eqs. (2) and (3)). In case of sufficient alkalinity, the formed $\mathrm{Fe}(\mathrm{II})$ can be further oxidized to $\mathrm{Fe}(\mathrm{III})$ by dissolved oxygen and other chemical oxidants, and Fe(III) (hydro)oxides can also be used for arsenic removal $[10,11]$. Sulfide acts as a reductant to convert $\mathrm{As}(\mathrm{V})$ to $\mathrm{As}(\mathrm{III})$ [12] and to form soluble and insoluble arsenic-sulfide complexes, e.g., di- and tri-thioarsenite monomers, dimeric and trimeric arsenic-sulfur complexes $[13,14]$. The precipitation of $\mathrm{As}_{2} \mathrm{~S}_{3}(\mathrm{am})$ occurs, and the dominant dissolved As species is dependent on sulfide levels, $\mathrm{pH}$, and temperature [15]. In the treatment of these AMD, the dominant factors affecting the removal of arsenic is far from being well understood.

$\mathrm{FeS} \stackrel{H^{+}}{\rightarrow} \mathrm{Fe}^{2+}+\mathrm{S}^{2-}$

$\mathrm{S}^{2-}+\mathrm{H}^{+} \rightarrow \mathrm{HS}$
$\mathrm{HS}^{-}+\mathrm{H}^{+} \rightarrow \mathrm{H}_{2} \mathrm{~S}$

This study aims to: 1) evaluate the removal efficiency of As(III) and $\mathrm{As}(\mathrm{V})$ by FeS over wide ranges of FeS doses and acidity; 2 ) indicate the dominant reactions involved in and the inhibiting effects in regarding to arsenic removal by $\mathrm{FeS} ; 3$ ) propose the strategy to optimize the utilization of FeS to treat high-As AMD.

\section{Materials and methods}

\subsection{Materials and reagents}

All the reagents used in this study were analytical grade. FeS powder was carefully ground and sieved, and the particle size was in the range from 200 to 300 mesh. The stock solutions of sodium arsenite $\left(\mathrm{NaAsO}_{2}\right)$ and sodium arsenate $\left(\mathrm{NaHAsO}_{4} \cdot 7 \mathrm{H}_{2} \mathrm{O}\right)$ at $10 \mathrm{~g} / \mathrm{L}$ as As were prepared in de-ionized water every 10 days whereas that of sodium sulfide $\left(\mathrm{Na}_{2} \mathrm{~S} \cdot 12 \mathrm{H}_{2} \mathrm{O}\right)$ was prepared just prior to use. As-containing water was prepared through spiking As stock solution into de-ionized water, and $\mathrm{H}_{2} \mathrm{SO}_{4}$ solution was added to provide the desired acidity. No background electrolyte was provided. The species distribution of $\mathrm{As}(\mathrm{III})$ and $\mathrm{As}(\mathrm{V})$ over wide $\mathrm{pH}$ ranges from -0.30 to -1.15 , i.e., the $\mathrm{H}_{2} \mathrm{SO}_{4}$ concentrations in the range from 1 to $7 \mathrm{~mol} / \mathrm{L}$, were calculated by the Visual MINTEQ software (Version 3.0, beta), and $\mathrm{H}_{3} \mathrm{AsO}_{3}$ and $\mathrm{H}_{3} \mathrm{AsO}_{4}$ are determined to be the dominant species of $\mathrm{As}(\mathrm{III})$ and $\mathrm{As}(\mathrm{V})$, respectively.

\subsection{Experimental Methods}

FeS doses were expressed by the molar ratios of FeS to As(III) and $\mathrm{As}(\mathrm{V})$, i.e., $\mathrm{R}_{\mathrm{FeS}: \mathrm{As}(\mathrm{III})}$ and $\mathrm{R}_{\mathrm{FeS}: \mathrm{As}(\mathrm{V}) \text {. The theoretical equivalent }}$ molar ratios of FeS to $\mathrm{As}(\mathrm{III})$ and $\mathrm{As}(\mathrm{V})$ were 1.5:1 and 2.5:1, as expressed in Eqs. (4) and (5). It was noted that the arsenic chemistry in sulfidic waters is rather complicate $[15,16]$, and the species distribution of As thioanion, mainly from $\mathrm{As}_{2} \mathrm{~S}_{3}$ dissolution, can be well predicted [16]. However, in this strongly-acidic wastewaters involve in this study, $\mathrm{As}_{2} \mathrm{~S}_{3}$ dissolution is greatly inhibited [15] and it is indicated as the dominant product in this study.

$3 \mathrm{FeS}+2 \mathrm{AsO}_{2}^{-}+8 \mathrm{H}^{+} \rightarrow 3 \mathrm{Fe}^{2+}+\mathrm{As}_{2} \mathrm{~S}_{3} \downarrow+4 \mathrm{H}_{2} \mathrm{O}$

$5 \mathrm{FeS}+2 \mathrm{HAsO}_{4}^{2-}+14 \mathrm{H}^{+} \rightarrow 5 \mathrm{Fe}^{2+}+\mathrm{As}_{2} \mathrm{~S}_{3} \downarrow+2 \mathrm{~S} \downarrow+8 \mathrm{H}_{2} \mathrm{O}$

When investigating the effects of acidity on the removal of As (III) and $\mathrm{As}(\mathrm{V})$ by FeS, $\mathrm{R}_{\mathrm{FeS}: \mathrm{As}(\mathrm{III})}$ and $\mathrm{R}_{\mathrm{FeS}: \mathrm{As}(\mathrm{V})}$ were $3: 1$ and $5: 1$ at two initial As concentration (i.e., [As] $]_{0}$ ) of 1000 and $3000 \mathrm{mg} / \mathrm{L}$. Batch experiments were conducted with magnetic stirring in capped $250-\mathrm{mL}$ flasks at room temperature. Soon after adding FeS powder at the desired amount into $100-\mathrm{mL}$ As solutions of predetermined concentrations in the flasks, the flasks were quickly capped and Vaseline was carefully smeared onto the bottle cork to ensure leak tightness and to avoid the dissipation of hydrogen sulfide $\left(\mathrm{H}_{2} \mathrm{~S}\right)$ gas. After 1-h stirring, the suspension was filtered by a $0.45-\mu \mathrm{m}$ membrane filter to analyze the concentrations of soluble $\mathrm{As}(\mathrm{III}), \mathrm{As}(\mathrm{V})$, total arsenic [ $\mathrm{As}(\mathrm{tot}), \mathrm{As}(\mathrm{III})+\mathrm{As}(\mathrm{V})]$, and iron in the filtrate. While investigating the effect of FeS doses on arsenic removal at $[\mathrm{As}]_{0}$ of 1000 and $3000 \mathrm{mg} / \mathrm{L}$, FeS doses over a wide range from $1: 1$ to $9: 1$ were investigated. In relatively low acidity ranges of 0.5 to $3 \mathrm{~mol} / \mathrm{L}$ as $\mathrm{H}_{2} \mathrm{SO}_{4}$, the elevated $\mathrm{FeS}$ doses of 8:1 as $\mathrm{R}_{\mathrm{FeS}: \mathrm{As}(\mathrm{III})}$ and $15: 1$ as $\mathrm{R}_{\mathrm{FeS}: \mathrm{As}(\mathrm{V})}$ were investigated. Similar procedures were followed when investigating the removal kinetics of arsenic by FeS except that sampling was carried out at intervals, and the FeS doses were 2.5:1 for $R_{\mathrm{FeS}: \mathrm{As}(\mathrm{III})}$ and 5:1 for $\mathrm{R}_{\mathrm{FeS}: \mathrm{As}(\mathrm{V}) \text {. }}$

To evaluate the removal behaviors of $\mathrm{Na}_{2} \mathrm{~S}$ towards $\mathrm{As}$ (III) and $\mathrm{As}(\mathrm{V})$, the $\mathrm{Na}_{2} \mathrm{~S}$ doses as expressed by the molar ratios of $\mathrm{Na}_{2} \mathrm{~S}$ to As, i.e., $R_{S: A s}$, ranged from 0.125:1 to 3:1, and the initial concentrations of $\mathrm{As}(\mathrm{III})$ and $\mathrm{As}(\mathrm{V})$ were $1000 \mathrm{mg} / \mathrm{L}$. The abovementioned procedures were followed. 


\subsection{Analysis and characterization}

The concentrations of As(tot) and Fe were determined by Inductively Coupled Plasma Optical Emission Spectroscopy (ICP-OES) (Optima 2000, PerkinElmer Co.). The concentrations of As(III) and As $(V)$ were measured with Hydride Generation Atomic Fluorescence Spectroscopy (HG-AFS), following the methods described in our previous study [17]. Soluble As(V) concentrations were calculated from the difference between the As(tot) and As(III) concentrations.

Electrokinetic potential ( $\zeta$ potential) was estimated from electrophoretic mobility using the Smoluchowski equation measured by a Zetasizer 2000 Zeta Potential Analyzer (Malvern Co., U.K.), and each sample was measured at least three times. The average volumetric particle diameter [AVPD, $\mathrm{d}(0.5)]$ and particle size distribution (PSD) were determined with a Mastersizer 2000 Laser Particle Size Analyzer (Malvern Co., U.K.). The $\zeta$ potential and PSD was directly measured without sample pretreatment, and it was noted that the precipitates were not analyzed at high acidity levels above $0.5 \mathrm{~mol} / \mathrm{L}$ as $\mathrm{H}_{2} \mathrm{SO}_{4}$.

The particle shapes and the elemental compositions were observed using a scanning electron microscope (SEM) with an EDAX KEVEX level 4 (Hitachi S-3500 N). The X-ray photoelectron spectroscopy (XPS) spectra were determined by an ESCA-Lab220i-XL spectrometer (Axis Ultra, UK) with monochromatic Al Ka radiation $(1486.6 \mathrm{eV})$. The XPS results were collected in binding energy form and fit using the software of Vision (PR2.1.3) and CasaXPS (2.3.12Dev7). After reactions, suspensions were filtered though $0.45-\mu \mathrm{m}$ membrane filters, and the residues were washed with ultra pure water several times and then freeze-dried. The obtained powders were kept in an air-tight container for use.

\section{Results and discussion}

\subsection{Removal behaviors of FeS towards $A s(I I I)$ and $A s(V)$ in strong} acidity

\subsubsection{Effects of acidity on the removal of $A s(I I I)$ and $A s(V)$}

The theoretical equivalent molar ratios between $\mathrm{FeS}$ and arsenic are 1.5:1 for $\mathrm{As}(\mathrm{III})$ and 2.5:1 for $\mathrm{As}(\mathrm{V})$, as indicated in Eqs. (4) and (5). Fig. 1 illustrates the removal efficiency of $\mathrm{As}(\mathrm{III})$ and $\mathrm{As}(\mathrm{V})$ by

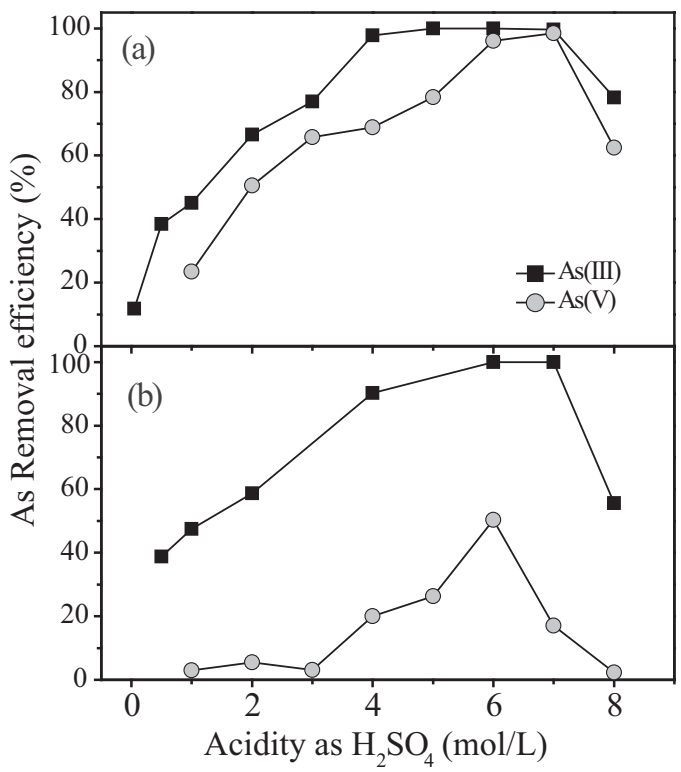

Fig. 1. Effects of acidity as $\mathrm{H}_{2} \mathrm{SO}_{4}$ on the removal of $\mathrm{As}(\mathrm{III})$ and $\mathrm{As}(\mathrm{V})$ by $\mathrm{FeS}$ $\left(\mathrm{a}:[\mathrm{As}]_{0}=1000 \mathrm{mg} / \mathrm{L}, \mathrm{b}:[\mathrm{As}]_{0}=3000 \mathrm{mg} / \mathrm{L} ; \mathrm{R}_{\mathrm{FeS}: \mathrm{As}(\mathrm{III})}=3: 1, \mathrm{R}_{\mathrm{FeS}: \mathrm{As}(\mathrm{V})}=5: 1\right)$.
FeS over a wide acidity range from 0.5 to $9 \mathrm{~mol} / \mathrm{L}$ as $\mathrm{H}_{2} \mathrm{SO}_{4}$. The FeS doses as expressed by $\mathrm{R}_{\mathrm{FeS}: \mathrm{As}(\mathrm{III})}$ and $\mathrm{R}_{\mathrm{FeS}: \mathrm{As}(\mathrm{V})}$ were $3: 1$ and $5: 1$, respectively. At initial As concentration (i.e., $[A s]_{0}$ ) of $1000 \mathrm{mg} / \mathrm{L}, \mathrm{As}(\mathrm{III})$ and $\mathrm{As}(\mathrm{V})$ showed little difference in removal efficiency (Fig. 1a), and the maximum removal achieved was as high as $99.8 \%$ for $\mathrm{As}(\mathrm{III})$ and $98.5 \%$ for $\mathrm{As}(\mathrm{V})$. At $[\mathrm{As}]_{0}=3000 \mathrm{mg} /$ L, the removal efficiency of As(III) was generally 30\% higher than that of $\mathrm{As}(\mathrm{V})$ (Fig. 1b), and the maximum removal was achieved at acidity of $6 \mathrm{~mol} / \mathrm{L}$ as $\mathrm{H}_{2} \mathrm{SO}_{4}$, and was determined to be $99.5 \%$ and $50.3 \%$ for $\mathrm{As}(\mathrm{III})$ and $\mathrm{As}(\mathrm{V})$, respectively.

The elevated acidity benefited the removal of these two As species; however, at extremely high acidity, above $6 \mathrm{~mol} / \mathrm{L}$ as $\mathrm{H}_{2} \mathrm{SO}_{4}$, both $\mathrm{As}(\mathrm{III})$ and $\mathrm{As}(\mathrm{V})$ showed decreased removal efficiency to a large extent. The increase of acidity to $8 \mathrm{~mol} / \mathrm{L}$ as $\mathrm{H}_{2} \mathrm{SO}_{4}$ decreased the removal efficiency to $55.6 \%$ for $\mathrm{As}(\mathrm{III})$ and to $2.3 \%$ for $\mathrm{As}(\mathrm{V})$ $\left([\mathrm{As}]_{0}=3000 \mathrm{mg} / \mathrm{L}\right)$. At $[\text { As }]_{0}$ of $1000 \mathrm{mg} / \mathrm{L}$ similar trends were also observed, and the removal efficiency decreased to $78.2 \%$ for $\mathrm{As}$ (III) and to $62.5 \%$ for $\mathrm{As}(\mathrm{V})$ accordingly. This was attributed to the oxidation of $\mathrm{S}(-\mathrm{II})$ to elemental $\mathrm{S}(0)$ by strong $\mathrm{H}_{2} \mathrm{SO}_{4}$ (Eq. (6)).

$\mathrm{FeS}+\mathrm{H}_{2} \mathrm{SO}_{4}+2 \mathrm{H}^{+} \rightarrow \mathrm{Fe}^{2+}+\mathrm{S} \downarrow+\mathrm{H}_{2} \mathrm{SO}_{3} \uparrow+\mathrm{H}_{2} \mathrm{O}$

\subsubsection{Effects of FeS doses on the removal of $A s(I I I)$ and $A s(V)$}

Fig. 2 indicates the positive effects of elevated $R_{\mathrm{Fes}}$ :As on the removal of $\mathrm{As}(\mathrm{III})$ and $\mathrm{As}(\mathrm{V})$ at two $[\mathrm{As}]_{0}$ of 1000 and $3000 \mathrm{mg} / \mathrm{L}$. Quantitatively, at $[\mathrm{As}]_{0}$ of $3000 \mathrm{mg} / \mathrm{L}$ the removal efficiency of As (III) increased from $29.0 \%$ to as high as nearly $100 \%$ with $\mathrm{R}_{\mathrm{FeS} \text { :As }}$ (III) increasing from $1: 1$ to $2.5: 1$, and that of $\mathrm{As}(\mathrm{V})$ increased from $1.2 \%$ to $86.7 \%$ with elevated $R_{\mathrm{Fes}: \mathrm{As}(\mathrm{V})}$ from $2: 1$ to $6: 1$. At lowered $[A s]_{0}$ of $1000 \mathrm{mg} / \mathrm{L}$, the elevated $\mathrm{R}_{\mathrm{Fes}}$ As also improved As removal. Comparatively, the removal efficiency of $\mathrm{As}(\mathrm{V})$ was lower than that

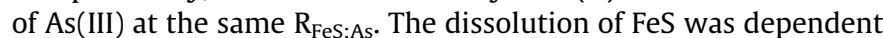
on acidity, and the effects of acidity on the removal of As(III) and As (V) by FeS ought to be similar. Interestingly, the required FeS dose as expressed by $\mathrm{R}_{\mathrm{FeS}: \mathrm{As}(\mathrm{V})}$ was much higher than the stoichiometric value. Comparatively, the gap between the required $\mathrm{R}_{\mathrm{Fes}: \mathrm{As}(\mathrm{III})}$ and the theoretical dose was much lower in the As(III)-removing system.

Results in Figs. 1 and 2 indicated the significance of the acidity and FeS doses on the removal of arsenic by FeS, and the elevated acidity and FeS doses were beneficial to the removal of arsenic.

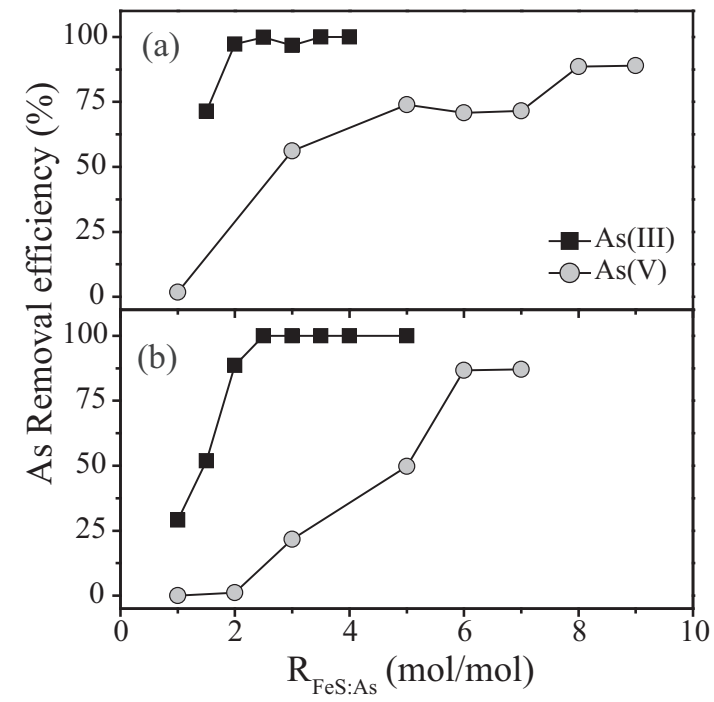

Fig. 2. Effects of FeS doses as expressed by $\mathrm{R}_{\mathrm{FeS}} \mathrm{As}$ on the removal of $\mathrm{As}(\mathrm{III})$ and $\mathrm{As}$ (V) by FeS (a: $[\mathrm{As}]_{0}=1000 \mathrm{mg} / \mathrm{L}$, acidity $=4 \mathrm{~mol} / \mathrm{L}$ as $\mathrm{H}_{2} \mathrm{SO}_{4}$; b: $[\mathrm{As}]_{0}=3000 \mathrm{mg} / \mathrm{L}$, acidity $=5 \mathrm{~mol} / \mathrm{L}$ as $\mathrm{H}_{2} \mathrm{SO}_{4}$ ) 


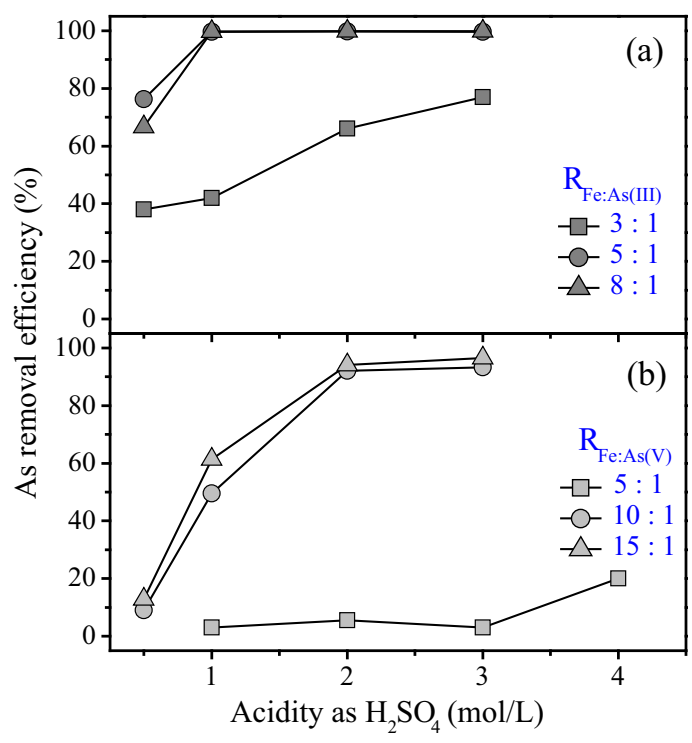

Fig. 3. Removal of $\mathrm{As}(\mathrm{III})$ and $\mathrm{As}(\mathrm{V})$ by FeS in relatively low acidity ranges (a: [As $\left.(\mathrm{III})]_{0}=3000 \mathrm{mg} / \mathrm{L}, \mathrm{b}:[\mathrm{As}(\mathrm{V})]_{0}=3000 \mathrm{mg} / \mathrm{L}\right)$.

In cases where the acidity in raw wastewater was relatively low, the addition of excessive acid was not feasible whereas the increase of FeS dose worked well. As indicated in Fig. 3, the elevation of $\mathrm{R}_{\mathrm{FeS}: \mathrm{As} \text { (III) }}$ from 3:1 to 5:1 contributed to the increase of As (III) removal efficiency from $42.3 \%$ to $99.6 \%$ (acidity $=1 \mathrm{~mol} / \mathrm{L}$ as $\mathrm{H}_{2} \mathrm{SO}_{4}$ ). At low acidity of $2 \mathrm{~mol} / \mathrm{L}$ as $\mathrm{H}_{2} \mathrm{SO}_{4}$, the removal efficiency of $\mathrm{As}(\mathrm{V})$ was as low as $5.5 \%$ at $\mathrm{R}_{\mathrm{FeS}: \mathrm{As}(\mathrm{V})}=5: 1$. $\mathrm{R}_{\mathrm{FeS}: \mathrm{As}(\mathrm{V})}$ at $10: 1$ and $15: 1$ significantly increased $\mathrm{As}(\mathrm{V})$ removal to $92.1 \%$ and to $94.1 \%$ accordingly.

\subsubsection{Removal kinetics of $A s(I I I)$ and $A s(V)$ by FeS}

Fig. 4 illustrates the removal kinetics of $\mathrm{As}(\mathrm{III})$ and $\mathrm{As}(\mathrm{V})$ by $\mathrm{FeS}$ at different $\mathrm{R}_{\mathrm{FeS} \text { :As }}$ with prolonged contact time. The removal of As (III) by FeS was remarkably faster than that of As(V). After 5-min contact time the removal efficiency of As(III) was $52.8 \%$ whereas that of $\mathrm{As}(\mathrm{V})$ was as low as $11.7 \%$ ([As $\left.]_{0}=1000 \mathrm{mg} / \mathrm{L}\right)$. After $60 \mathrm{~min}$, the removal efficiency of As(III) was $99.5 \%$ and $75.7 \%$ at $[\mathrm{As}]_{0}$ of 1000 and $5000 \mathrm{mg} / \mathrm{L}$, respectively. The removal of $\mathrm{As}(\mathrm{V})$ by FeS was much slower, and after 210 min the removal of As(V) was as low as $69.9 \%\left([\mathrm{As}]_{0}=1000 \mathrm{mg} / \mathrm{L}\right)$.

The formation of $\mathrm{As}_{2} \mathrm{~S}_{3}$ precipitates upon acidification of samples containing arsenic and sulfide has also been demonstrated

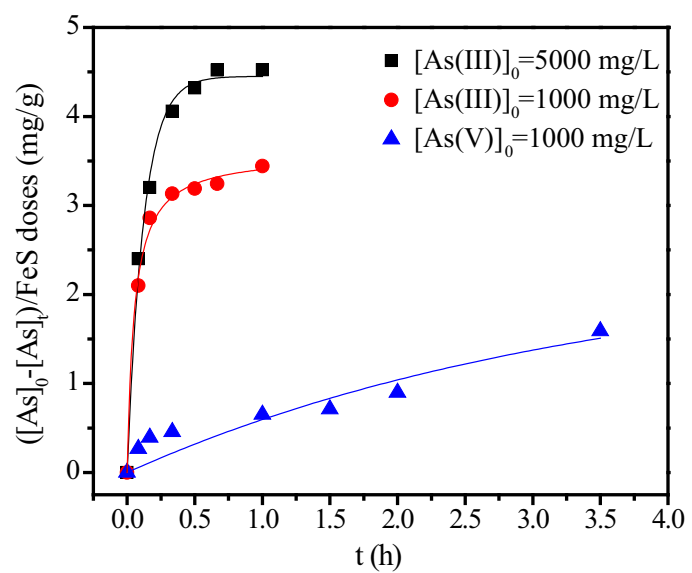

Fig. 4. The removal kinetics of $\mathrm{As}(\mathrm{III})$ and $\mathrm{As}(\mathrm{V})$ by FeS at different $\mathrm{R}_{\mathrm{FeS}: \mathrm{As}}(\mathbf{\square}-3 \mathrm{~mol} /$ $\mathrm{L}$ as $\mathrm{H}_{2} \mathrm{SO}_{4}, \mathrm{R}_{\mathrm{FeS}: \mathrm{As}(\mathrm{III})}=2.5: 1 ;-4 \mathrm{~mol} / \mathrm{L}$ as $\mathrm{H}_{2} \mathrm{SO}_{4}, \mathrm{R}_{\mathrm{FeS}: \mathrm{As}(\mathrm{III})}=5: 1 ; \boldsymbol{\Delta}^{-4} \mathrm{~mol} / \mathrm{L}$ as $\left.\mathrm{H}_{2} \mathrm{SO}_{4}, \mathrm{R}_{\mathrm{FeS}: \mathrm{As}(\mathrm{V})}=2.5: 1\right)$. before [18], and the rapid As(III) removal may be attributed to the rapid formation of $\mathrm{As}_{2} \mathrm{~S}_{3}$ precipitate formed by $\mathrm{As}(\mathrm{III})$ and the dissolved S(-II) (Eq. (7)). The removal of As(V) by FeS was more complicated (Eq. (8)). Prior to the formation of $\mathrm{As}_{2} \mathrm{~S}_{3}$ precipitates, the reduction of $\mathrm{As}(\mathrm{V})$ to $\mathrm{As}(\mathrm{III})$ occurred first (Eq. (9)). This redox reaction may be the rate-limiting step in $\mathrm{As}(\mathrm{V})$ removal.

$2 \mathrm{As}(\mathrm{III})+3 \mathrm{~S}(-\mathrm{II}) \rightarrow \mathrm{As}_{2} \mathrm{~S}_{3} \downarrow+\mathrm{H}_{2} \mathrm{O}$

$2 \mathrm{As}(\mathrm{V})+5 \mathrm{~S}(-\mathrm{II}) \rightarrow \mathrm{As}_{2} \mathrm{~S}_{3} \downarrow+2 \mathrm{~S}(0) \downarrow+3 \mathrm{H}_{2} \mathrm{O}$

$\mathrm{As}(\mathrm{V})+\mathrm{S}(-\mathrm{II}) \rightarrow \mathrm{As}(\mathrm{III})+\mathrm{S}(0) \downarrow+\mathrm{H}_{2} \mathrm{O}$

\subsection{Reduction of $A s(V)$ to $A s(I I I)$ in the removal of $A s(V)$ by FeS}

SEM/EDS analysis indicated the presence of low Fe ratios below $3 \%$ on the surfaces of the formed precipitates. It was inferred that the dissolved $\mathrm{Fe}^{2+}$ played little role, whereas the sulfur [S(-II), i.e., $\mathrm{S}^{2-}, \mathrm{HS}^{-}, \mathrm{H}_{2} \mathrm{~S}$ ] dominated in the removal of arsenic by FeS. To confirm this, the removal of $\mathrm{As}(\mathrm{III})$ and $\mathrm{As}(\mathrm{V})$ by $\mathrm{Na}_{2} \mathrm{~S}$ with elevated $\mathrm{R}_{\mathrm{S}}$ : As was investigated, and the elevated $R_{S}$ :As was related to more significant removal of both As species (Fig. 5). At $\mathrm{R}_{\mathrm{S}: \text { As }}$ of below 1.5:1, i.e., the equivalent molar ratio of $\mathrm{S}(-\mathrm{II})$ to $\mathrm{As}$ (III) to form $\mathrm{As}_{2} \mathrm{~S}_{3}$ (Eq. (7)), As(III) showed much higher removal efficiency than As(V) did. At elevated $R_{S: A s}$ of $2.5: 1$, i.e., the equivalent molar ratio of $S(-I I)$ to $\mathrm{As}(\mathrm{V})$ (Eq. (8)), the removal efficiency of $\mathrm{As}(\mathrm{V})$ was nearly $100 \%$. FeS may act as a sulfur source to provide $\mathrm{S}(-\mathrm{II})$ available for the reduction of $\mathrm{As}(\mathrm{V})$ to $\mathrm{As}(\mathrm{III})$ and the formation of $\mathrm{As}_{2} \mathrm{~S}_{3}$ thereafter. However, the required FeS doses to achieve high $\mathrm{As}(\mathrm{V})$ removal as expressed by $R_{\mathrm{FeS}: \mathrm{As}(\mathrm{V})}$ in Fig. 2 were much higher than $R_{\mathrm{S}: \mathrm{As}(\mathrm{V})}$. By comparison, much less difference between $\mathrm{R}_{\mathrm{S}: \mathrm{As}(\mathrm{III})}$ and $\mathrm{R}_{\mathrm{FeS}: \mathrm{As}(\mathrm{III})}$ was observed to achieve the same As(III) removal.

The analysis of $\mathrm{As}(\mathrm{III})$ concentrations indicated the reduction of $\mathrm{As}(\mathrm{V})$ to $\mathrm{As}(\mathrm{III})$ by FeS in the As(V)-removing system (Fig. S1). However, $\mathrm{As}(\mathrm{V})$ was the dominant species over a wide $\mathrm{R}_{\mathrm{FeS}: \mathrm{As}(\mathrm{V})}$ range, as indicated by the high ratios of $\mathrm{As}(\mathrm{V})$ to $\mathrm{As}($ tot $)$, i.e., $\mathrm{R}_{\mathrm{As}(\mathrm{V}) \text { : } \mathrm{As}(\mathrm{tot}) \text {. }}$ Upon the reduction of $\mathrm{As}(\mathrm{V})$ to $\mathrm{As}(\mathrm{III}), \mathrm{As}(\mathrm{III})$ was inferred to rapidly form $\mathrm{As}_{2} \mathrm{~S}_{3}$ precipitates. The consumption of $\mathrm{As}(\mathrm{III})$ was observed to be dependent on acidity. At extremely high acidity of $8 \mathrm{~mol} / \mathrm{L}$, the formed sulfide (i.e., $\mathrm{H}_{2} \mathrm{~S}$ ) was oxidized by $\mathrm{H}_{2} \mathrm{SO}_{4}$ to $\mathrm{S}$ (0) (Eq. (10)). This effect greatly inhibited the formation of $\mathrm{As}_{2} \mathrm{~S}_{3}$, and $\mathrm{R}_{\mathrm{As}(\mathrm{V}): \mathrm{As}(\text { tot })}$ was observed to be near to 0 .

$\mathrm{H}_{2} \mathrm{~S}+\mathrm{H}_{2} \mathrm{SO}_{4} \rightarrow \mathrm{S} \downarrow+\mathrm{H}_{2} \mathrm{SO}_{3} \uparrow+\mathrm{H}_{2} \mathrm{O}$

XPS analysis further confirmed the dominant reactions involved in the removal of $\mathrm{As}(\mathrm{III})$ and $\mathrm{As}(\mathrm{V})$ by FeS. The observed elemental ratios of $S$ to $A s\left(R_{S: A s}\right)$, as indicated from Table 1, were near the theoretical stoichiometric ratios as calculated from Eqs. (4) and

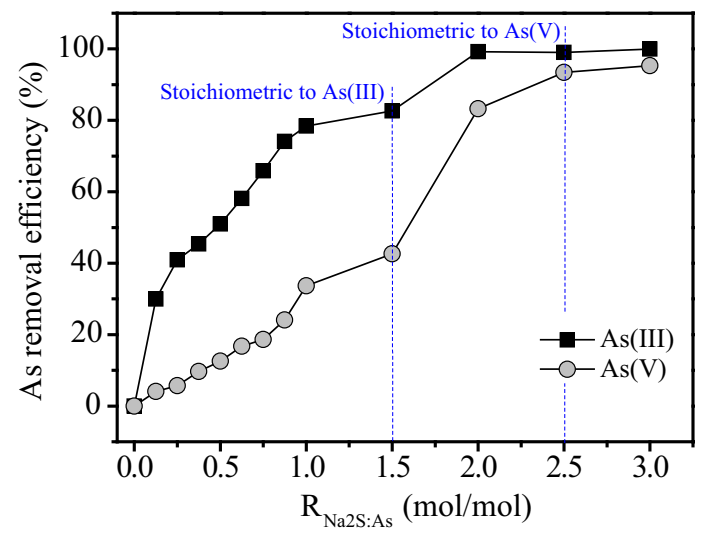

Fig. 5. The removal of $\mathrm{As}(\mathrm{III})$ and $\mathrm{As}(\mathrm{V})$ by $\mathrm{Na}_{2} \mathrm{~S}$ with elevated $\mathrm{R}_{\mathrm{Na}_{2} \mathrm{~S}: \mathrm{As}}$ $\left([\mathrm{As}]_{0}=1000 \mathrm{mg} / \mathrm{L}\right.$, acidity $=0.5 \mathrm{~mol} / \mathrm{L}$ as $\left.\mathrm{H}_{2} \mathrm{SO}_{4}\right)$. 
Table 1

Surface atomic compositions derived from the peak areas of $\mathrm{As}(3 \mathrm{~d})$ and $\mathrm{S}(2 \mathrm{p})$ components in survey XPS spectra and SEM/EDS analysis.

\begin{tabular}{|c|c|c|c|c|c|c|}
\hline \multirow[t]{2}{*}{ Elements } & \multicolumn{2}{|c|}{ SEM/EDS (Atomic ratios) } & \multicolumn{2}{|c|}{ XPS (Atomic ratios) } & \multicolumn{2}{|l|}{ XPS (Binding energy) } \\
\hline & $\begin{array}{l}\text { As(III) removing } \\
\text { system (\%) }\end{array}$ & $\begin{array}{l}\text { As(V) removing } \\
\text { system (\%) }\end{array}$ & $\begin{array}{l}\text { As(III) removing } \\
\text { system (\%) }\end{array}$ & $\begin{array}{l}\text { As(V) removing } \\
\text { system (\%) }\end{array}$ & $\begin{array}{l}\text { As(III) removing system } \\
(\mathrm{eV})\end{array}$ & $\begin{array}{l}\mathrm{As}(\mathrm{V}) \text { removing system } \\
(\mathrm{eV})\end{array}$ \\
\hline As & 44.25 & 35.74 & 14.27 & 8.60 & 43.7 & 43.3 \\
\hline $\mathrm{S}$ & 53.14 & 61.90 & 22.55 & 19.36 & 162.6 & 163.2 \\
\hline $\mathrm{R}_{\mathrm{S}: \mathrm{As}}$ & $1.20: 1$ & $1.73: 1$ & $1.58: 1$ & $2.25: 1$ & 1 & 1 \\
\hline
\end{tabular}

(5). SEM/EDS analysis, on the basis of at least three randomly selected locations, also indicated the presence of a sulfurenriched surface in the $A s(\mathrm{~V})$-removing system. The reduction of $\mathrm{As}(\mathrm{V})$ to $\mathrm{As}(\mathrm{III})$ and the formation of $\mathrm{As}_{2} \mathrm{~S}_{3}$ precipitates was inferred to dominate in the removal of $\mathrm{As}(\mathrm{V})$ by FeS. It should be noted that the formation of other products such as disulfide $\left(\mathrm{S}_{2}^{2-}\right)$, polysulfide $\left(\mathrm{S}_{\mathrm{n}}^{2-}\right)$ and thioarsenate (e.g., $\mathrm{AsO}_{3} \mathrm{~S}^{3-}, \mathrm{AsO}_{2} \mathrm{~S}^{3-}$ ) may also occur $[7,19]$.

XPS survey scans indicated the presence of $\mathrm{S}, \mathrm{As}, \mathrm{O}$, and $\mathrm{C}$. Adventitious carbon $[\mathrm{C}(1 \mathrm{~s})]$ was observed in both samples, and the atomic ratios of $\mathrm{O}(1 \mathrm{~s})$ were as low as below $2 \%$. Fig. 6 illustrates the narrow As(3d) XPS spectra for these two precipitates, and the sharp peaks indicate the existence of one prominent species. The As(3d) binding energy, as determined at 43.7 and $43.3 \mathrm{eV}$, may be attributed to the $\mathrm{As}(+\mathrm{III})$ within $\mathrm{As}_{2} \mathrm{~S}_{3}$. Han et al. (2011) investigated the XPS spectra of As 3d peaks for several As-related model components, and indicated that the position of the $A s 3 \mathrm{~d}_{5 / 2}$ peak for arsenic(III) sulfide (i.e., $\mathrm{As}_{2} \mathrm{~S}_{3}$ ) was $43.2 \mathrm{eV}$ [20]. Corkhill et al. (2006) investigated the charge-corrected binding energies for the photoelectrons emitted from a natural orpiment crystal $\left(\mathrm{As}_{2} \mathrm{~S}_{3}\right)$, which was collected from Twin Creeks Mine, Nevada and was fractured along the [010] cleavage plane, and the binding energies of $\mathrm{As}(3 \mathrm{~d})$ and $\mathrm{S}(2 \mathrm{p})$ were reported to be 43.5 and $162.3 \mathrm{eV}$ [21]. The observed slight shift in the binding energies may be attributed to several effects such as surface charging involved in X-ray photoemission [22]. The precipitates formed in the As(III)-removing system showed the $\mathrm{S}(2 \mathrm{p})$ binding energy of $162.6 \mathrm{eV}$, which was assigned to the sulfide ion [S(-II)] [23]. In the As(V)-removing system, the $S(2 p)$ binding energy showed a $0.9 \mathrm{eV}$ shift to higher energy at $163.2 \mathrm{eV}$, and indicated the existence of elemental sulfur $[S(0)]$ at higher binding energy [24].

\subsection{The formation of $S(0)$ and its effect on $A s(V)$ removal by FeS}

The removal of arsenic by $\mathrm{Na}_{2} \mathrm{~S}$ was slightly dependent on acidity over a wide acidity range, and the low acidity condition of
$0.02 \mathrm{~mol} / \mathrm{L}$ as $\mathrm{H}_{2} \mathrm{SO}_{4}$ was sufficient to achieve the reduction of As (V) to $\mathrm{As}$ (III) and the formation of $\mathrm{As}_{2} \mathrm{~S}_{3}$ (Fig. S2). After the dissolution of FeS to soluble $\mathrm{S}(-\mathrm{II})$, the homogeneous reactions between soluble S(-II) and arsenic, as indicated in Eqs. (7) and (8), may be easily achieved. Consequently, the dissolution of FeS was the rate-limiting step for the removal of arsenic by FeS.

Additionally, FeS showed remarkably different removal behaviors towards $\mathrm{As}(\mathrm{III})$ and $\mathrm{As}(\mathrm{V})$, and this may be attributed to the inhibitive effects of formed $S(0)$. First, the formation of $S(0)$ may inhibit FeS dissolution. Fig. S3 illustrates the dissolved Fe concentrations $\left(\mathrm{Fe}_{\mathrm{dis}}\right)$ with elevated acidity for the As(III)- and $\mathrm{As}(\mathrm{V})-$ removing systems, and the calculated $\mathrm{Fe}_{\mathrm{dis}}$ values equivalent to the removed arsenic are also indicated. Compared to the $\mathrm{As}(\mathrm{V})-$ removing system, the As(III)-removing system showed much higher $\mathrm{Fe}_{\mathrm{dis}}$, i.e., more significant $\mathrm{FeS}$ dissolution, and a more remarkable difference between the observed and calculated $\mathrm{Fe}_{\mathrm{dis}}$ was also observed. The formation of $\mathrm{S}(0)$ in the $\mathrm{As}(\mathrm{V})$-removing system may dominate in inhibiting FeS dissolution. This was supported by the obviously decreased $\mathrm{Fe}_{\text {dis }}$ at the extremely high acidity level of $7 \mathrm{~mol} / \mathrm{L}$ as $\mathrm{H}_{2} \mathrm{SO}_{4}$ in the $\mathrm{As}(\mathrm{III})$-removing system. In this case the heterogeneous oxidation of $\mathrm{S}(-\mathrm{II})$ within $\mathrm{FeS}$ by $\mathrm{H}_{2} \mathrm{SO}_{4}$ occurred to form $\mathrm{S}(0)$ on the FeS surface, and $\mathrm{S}(0)$ acted as a barrier to inhibit FeS dissolution and the release of $\mathrm{Fe}^{2+}$ or $\mathrm{S}(-\mathrm{II})$ thereafter.

The formed $S(0)$ may tend to coat onto the FeS surface to inhibit further FeS dissolution. Unfortunately, this assumption cannot be demonstrated by characterizing FeS surfaces because FeS particles cannot be precisely separated from the $\mathrm{As}_{2} \mathrm{~S}_{3}$ precipitates to analyze their surfaces. To give more information to support this assumption, we prepared two precipitates from the reactions between $\mathrm{Na}_{2} \mathrm{~S}$ and these two As species and then analyzed their particle size distribution (PSD) and $\zeta$-potential. Note that the acidity used, as indicated by equilibrium $\mathrm{pH}$, was higher than $\mathrm{pH} 1$ to avoid detrimental effects on these instruments at extremely high acidity. The obtained results of PSD and $\zeta$-potential may be different from those in strongly-acidic $\mathrm{pH}$ conditions; however, these results are expected to benefit the optimization of $\mathrm{pH}$ adjustment
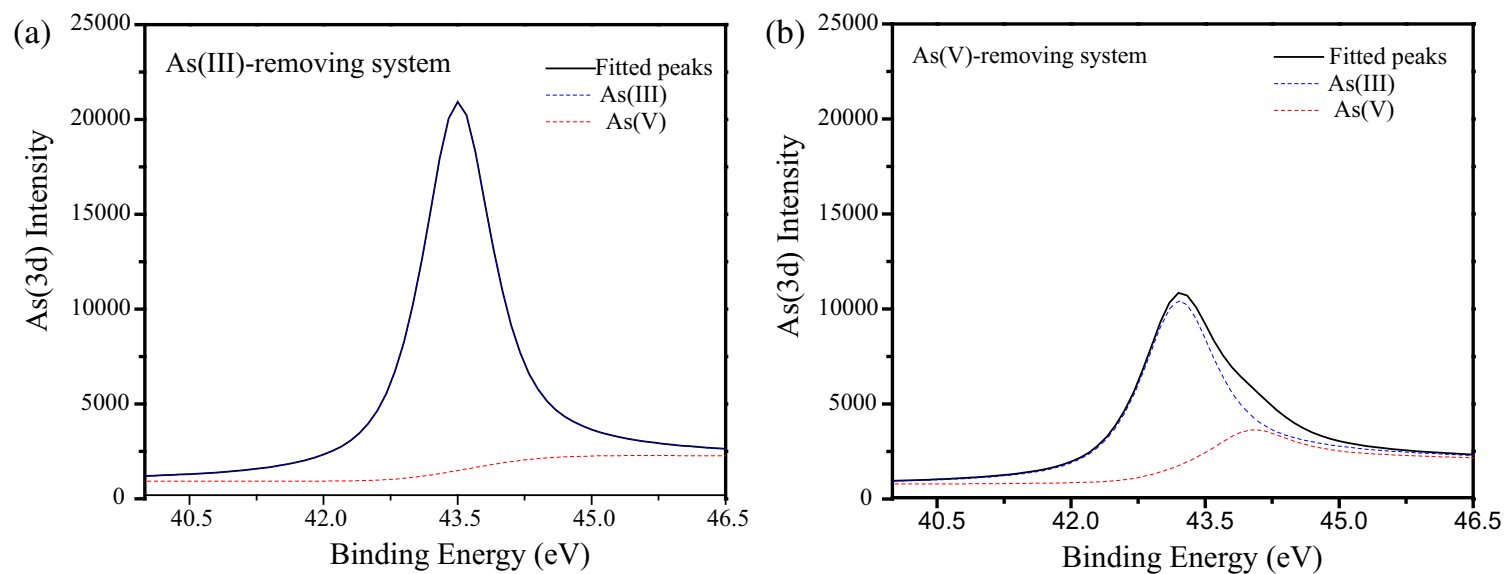

Fig. 6. XPS spectra of As(3d) peaks for the precipitates formed in the removal of (a) As(III) and (b) As(V) by FeS. 


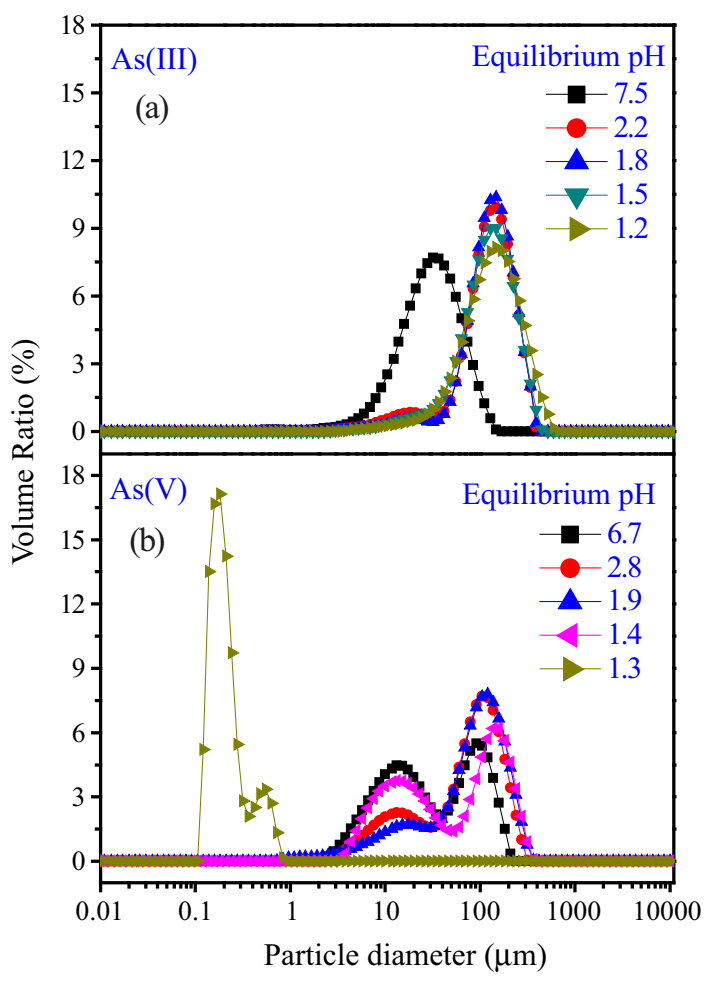

Fig. 7. The particles size distribution of the formed precipitates in the removal of (a) $\mathrm{As}(\mathrm{III})$ and (b) $\mathrm{As}(\mathrm{V})$ by $\mathrm{Na}_{2} \mathrm{~S}$ over a wide $\mathrm{pH}$ range ([As $]_{0}=1000 \mathrm{mg} / \mathrm{L}$; $\left.\mathrm{R}_{\mathrm{Na}_{2} \mathrm{~S}: \mathrm{As}}=1: 1\right)$.

and precipitates separation in considering that $\mathrm{pH}$ neutralization is inevitable to treat these acidic wastewaters. Fig. 7 indicates that the precipitates formed in the As(III)-removal system showed much higher particle diameter than those formed in the $\mathrm{As}(\mathrm{V})$ removal system over a wide equilibrium $\mathrm{pH}$ range from 1 to 8 . The precipitate formed in the As(III)-removing system appeared to be loose and large flocs, and its volume average diameter as expressed by $\mathrm{d}(0.5)$ showed slight variation in the equilibrium $\mathrm{pH}$ range from 1 to 2.5 (Fig. S4). Additionally, only one peak in the plot of volume percentage vs. particle diameter was observed (Fig. 7a), and this indicated that this precipitate was uniform in particle diameter. By comparison, the precipitate formed in the $\mathrm{As}(\mathrm{V})$-removing system appeared to consist of compact and tiny particles with much lower $\mathrm{d}(0.5)$ values. These precipitates were unevenly distributed with two main peaks (Fig. 7b), possibly owing to the coexisting precipitates of $\mathrm{As}_{2} \mathrm{~S}_{3}$ and $\mathrm{S}(0)$.

These two precipitates also showed critically different $\zeta$ potential variation trends. In the As(III)-removing system, the $\zeta$ potential of the precipitate decreased from $-14.6 \mathrm{mV}$ to $-34.1 \mathrm{mV}$ with $\mathrm{pH}$ increasing from 1.8 to 7.5. In comparison, much lower $\zeta$-potentials were observed in the $\mathrm{As}(\mathrm{V})$-removing system, determined to be $-47.7 \mathrm{mV}$ at $\mathrm{pH} 1.9$ and $-56.7 \mathrm{mV}$ at $\mathrm{pH}$ 6.7. The lower $\zeta$-potential inhibited aggregation and formation of larger particles, as indicated by the positive correlation between $\zeta$ potential and $\mathrm{d}(0.5)$ values. The $\mathrm{d}(0.5)$ values decreased from 132.5 to $30.9 \mu \mathrm{m}$ with $\mathrm{pH}$ increasing from 1.8 to 7.5 in the As (III)-removing system. In the $\mathrm{As}(\mathrm{V})$-removing system, $\mathrm{d}(0.5)$ also decreased from $95.5 \mu \mathrm{m}$ at $\mathrm{pH} 1.9$ to $29.5 \mu \mathrm{m}$ at $\mathrm{pH}$ 6.7. The tiny precipitates with low $\zeta$-potential, as formed in the $\mathrm{As}(\mathrm{V})$ removing system, were assumed to coat onto FeS surfaces.

The dominant reactions involved in the removal of $\mathrm{As}(\mathrm{III})$ and $\mathrm{As}(\mathrm{V})$ by $\mathrm{FeS}$ and the inhibitive effects of $\mathrm{S}(0)$ are proposed and illustrated in Fig. 8. In strong acidity, FeS dissolved into $\mathrm{Fe}^{2+}$ and $\mathrm{S}(-\mathrm{II})$, and the formation of $\mathrm{As}_{2} \mathrm{~S}_{3}$ between $\mathrm{S}(-\mathrm{II})$ and $\mathrm{As}(\mathrm{III})$ directly occurred without redox reactions. Additionally, a heterogeneous

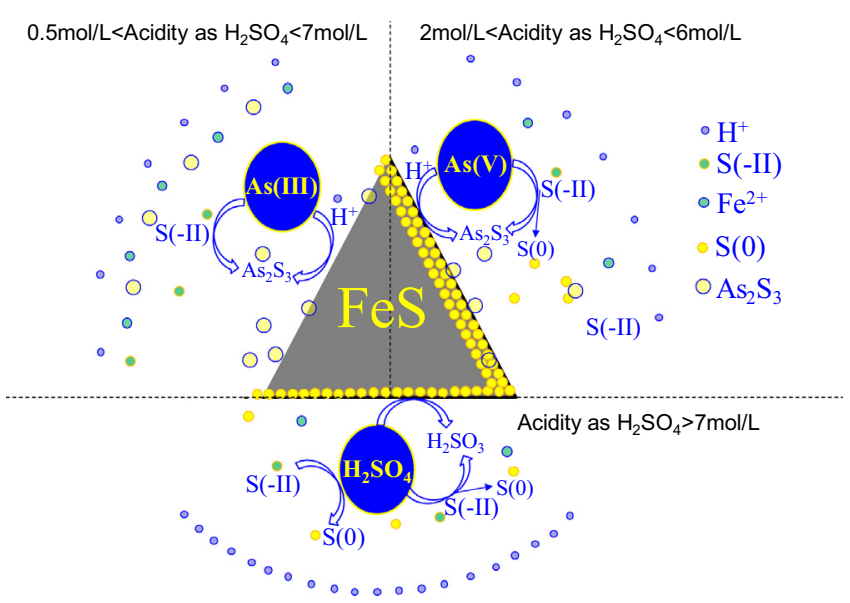

Fig. 8. Proposed schematic on the inhibitive effects of $S(0)$ on the removal of $A s(I I I)$ and $\mathrm{As}(\mathrm{V})$ by FeS.

reaction between $\mathrm{As}(\mathrm{III})$ and FeS also occurred to form loose and large $\mathrm{As}_{2} \mathrm{~S}_{3}$ flocs. These flocs rapidly detached from the FeS surface and showed little inhibition of either FeS dissolution or $\mathrm{As}_{2} \mathrm{~S}_{3}$ formation. In the presence of $A s(V)$, however, the tiny $S(0)$ particles tended to coat onto the FeS surface to inhibit its dissolution thereafter. At extremely high acidity, $\mathrm{H}_{2} \mathrm{SO}_{4}$ showed strong activity to oxidize $\mathrm{S}(-\mathrm{II})$ to $\mathrm{S}(0)$ with standard electrode potential of $0.479 \mathrm{~V}$ (Eq. (11)), and the formation of $S(0)$ coating on FeS surfaces inhibited the removal of either arsenic species thereafter.

$\mathrm{SO}_{4}^{2-}+\mathrm{H}_{2} \mathrm{~S}(\mathrm{aq})+6 \mathrm{H}^{+}+4 \mathrm{e}^{-} \rightarrow 2 \mathrm{~S}(0) \downarrow+\mathrm{H}_{2} \mathrm{SO}_{3}+4 \mathrm{H}_{2} \mathrm{O}$

\subsection{Implication for the treatment of high-As AMD by FeS}

The abovementioned results indicate the feasibility of using FeS powder as the sources of $\mathrm{Fe}(\mathrm{II})$ and $\mathrm{S}(-\mathrm{II})$ for the treatment of AMD. As for the economic evaluation, the initial arsenic concentration is assumed to be $3000 \mathrm{mg} / \mathrm{L}$ and the ratio of $\mathrm{As}(\mathrm{III})$ to $\mathrm{As}(\mathrm{V})$ to be $1: 1$, and the acidity is assumed to be sufficient. The cost of the industrial FeS powder is $700 \$ /$ ton. The theoretical FeS doses as indicated by stoichiometric calculation are $80 \mathrm{mmol} / \mathrm{L}\left(\sim 7 \mathrm{~g} / \mathrm{L}=7 \mathrm{~kg} / \mathrm{m}^{3}\right)$. In practice, FeS should be overdosed to achieve good As removal efficiency, and the optimized FeS doses ( $\left.\mathrm{R}_{\mathrm{FeS}} \mathrm{As}\right)$ are $2: 1$ for $\mathrm{As}(\mathrm{III})$ and $6: 1$ for $\mathrm{As}(\mathrm{V})$ (Fig. 2). The total FeS dose is determined to be $160 \mathrm{mmol} / \mathrm{L}\left(\sim 14 \mathrm{~g} / \mathrm{L}=14 \mathrm{~kg} / \mathrm{m}^{3}\right)$, and the cost for FeS is calculated to be $9.8 \$ / \mathrm{m}^{3}$. It is noted that in the continuous process, the extra FeS powder could be easily separated and then circulated into the raw water for reclamation. This would decrease the cost by half to be $4.9 \$ / \mathrm{m}^{3}$. The economic evaluation indicates the priority of using FeS powder in terms of treatment cost.

FeS cannot achieve the permitted discharging concentrations of the Chinese Industrial Wastewater Discharge Standard $(<0.5 \mathrm{mg} / \mathrm{L})$, and further treatment processes are required and the dissolved Fe (II) may be used. Fig. 9 illustrates the strategy for the treatment of high-As AMD by FeS and the dominant reactions involved therein. First, the dissolution of FeS consumes acidity, and stoichiometric calculation indicates that the removal of $3000 \mathrm{mg} / \mathrm{L} \mathrm{As}$ (III) and As (V) consumes 0.16 and $0.28 \mathrm{~mol} / \mathrm{L}$ as $\mathrm{H}^{+}$, respectively. Additionally, FeS dissolves into $\mathrm{Fe}^{2+}$ and $\mathrm{S}(-\mathrm{II})$, and these two species are valuable for arsenic removal. The homogeneous reactions between arsenic and soluble $\mathrm{S}(-\mathrm{II})$ achieve the rapid removal of both As (III) and $\mathrm{As}(\mathrm{V})$ with $\mathrm{As}_{2} \mathrm{~S}_{3}$ as the dominant species, although the formation of other arsenic-sulfur intermediates such as thioarsenite monomers occurs and is rather complicated $[7,13,14,19]$. Additionally, heterogeneous reactions between As(III) and the FeS surface also play an important role. The prompt detachment of 


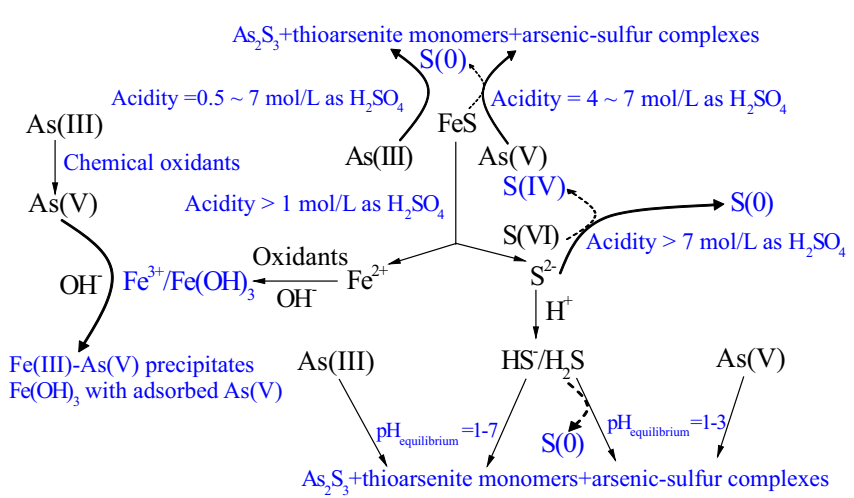

Fig. 9. The dominant reactions involve in the treatment of acidic high-As wastewater with by FeS and the proposed strategy for FeS application.

$\mathrm{As}_{2} \mathrm{~S}_{3}$ maintains fresh FeS surfaces, and this benefits FeS dissolution and $\mathrm{As}_{2} \mathrm{~S}_{3}$ formation (Fig. 8). In the presence of $\mathrm{As}(\mathrm{V})$, unfortunately, the coating of $\mathrm{S}(0)$ on FeS surfaces acts as a barrier to isolate FeS and inhibits the removal of arsenic. The elevated FeS doses may alleviate this adverse effect to some extent; however, the conversion of $\mathrm{As}(\mathrm{V})$ to $\mathrm{As}(\mathrm{III})$ by $\mathrm{Na}_{2} \mathrm{~S}$ prior to dosing FeS may be more cost-effective and practically valuable. At extremely high acidity, the oxidization of $\mathrm{S}(-\mathrm{II})$ to $\mathrm{S}(0)$ by strong $\mathrm{H}_{2} \mathrm{SO}_{4}$ also inhibits arsenic removal, and sufficient alkalinity is required to avoid this side effect. After the formation of $\mathrm{As}_{2} \mathrm{~S}_{3}$ and $\mathrm{S}(0)$ precipitates, particulate As may be removed by solid-liquid separation. Furthermore, the addition of oxidants such as $\mathrm{O}_{2}$ and chorine and $\mathrm{pH}$ adjustment by increasing alkalinity can be carefully managed to achieve the oxidation of $\mathrm{Fe}(\mathrm{II})$ to $\mathrm{Fe}(\mathrm{III})$, the formation of $\mathrm{Fe}$-As precipitates, and the adsorption of arsenic onto $\mathrm{Fe}(\mathrm{OH})_{3}$. The addition of extra $\mathrm{Fe}(\mathrm{III})$ and chemical oxidants may be preferred to achieve better removal efficiency.

\section{Conclusion}

FeS acts as a source of Fe(II) and S(-II) and is feasible and costeffective to treat high-arsenic AMD. The formation of $\mathrm{As}_{2} \mathrm{~S}_{3}$ precipitates between $\mathrm{S}(-\mathrm{II})$ and $\mathrm{As}(\mathrm{III})$ rapidly occurs to achieve good As (III) removal. In the $\mathrm{As}(\mathrm{V})$-removing system, the formation of $\mathrm{S}(0)$ and $S(0)$-rich surfaces greatly inhibits the removal of $A s(V)$ by FeS. The conversion of $\mathrm{As}(\mathrm{V})$ to $\mathrm{As}(\mathrm{III})$ prior to dosing with $\mathrm{FeS}$ is recommended to avoid the coating of $S(0)$ onto the FeS surface. The adverse effect of $\mathrm{S}(0)$ also occurs at extremely high acidity above $7 \mathrm{~mol} / \mathrm{L}$ as $\mathrm{H}_{2} \mathrm{SO}_{4}$, and this can be avoided by increasing alkalinity to the preferred acidity range of 6-7 mol/L to favor FeS dissolution. It is noted that the obtained sludge mainly includes $\mathrm{As}_{2} \mathrm{~S}_{3}$ precipitate and $S(0)$ and the As content is extremely high. This sludge must be safely disposed of by cheap and convenient means such as solidification in roadbed or encapsulation in cement-lime mixture to avoid secondary pollution to environments.

\section{Acknowledgments}

This work was supported by Major Science and Technology Program for Water Pollution Control and Treatment (No. 2010ZX07212-007) and the National Natural Science Foundation of China (Grant Nos. 51422813 and 512218920). Moreover, the author Ruiping Liu gratefully acknowledges the support of Beijing Nova Program - 'China' (2013054).

\section{Appendix A. Supplementary data}

Supplementary data associated with this article can be found, in the online version, at http://dx.doi.org/10.1016/j.cej.2016.05.109.

\section{References}

[1] P.L. Smedley, D.G. Kinniburgh, A review of the source, behaviour and distribution of arsenic in natural waters, Appl. Geochem. 17 (2002) 517-568.

[2] Ministry of Environmental Protection of the People's Republic of China, Integrated Wastewater Discharge Standard (GB8978-1996), China Environment Science Press, Beijing, 1996.

[3] A.I. Zouboulis, K.A. Kydros, K.A. Matis, Arsenic(III) and arsenic(V) removal from solutions by Pyrite fines, Sep. Sci. Technol. 28 (1993) 2449-2463.

[4] F.L. Sun, B.A. Dempsey, K.A. Osseo-Asare, As(V) and As(III) reactions on pristine pyrite and on surface-oxidized pyrite, J. Colloid Interface Sci. 388 (2012) 170175.

[5] E.J. Kim, B. Batchelor, Macroscopic and X-ray photoelectron spectroscopic investigation of interactions of arsenic with synthesized pyrite, Environ. Sci. Technol. 43 (2009) 2899-2904.

[6] M.L. Farquhar, J.M. Charnock, F.R. Livens, D.J. Vaughan, Mechanisms of arsenic uptake from aqueous solution by interaction with goethite, lepidocrocite mackinawite, and pyrite: an X-ray absorption spectroscopy study, Environ. Sci. Technol. 36 (2002) 1757-1762.

[7] R. Devon, G. Tanya, U. Satoshi, H. Kim, C.E. Rodney, B. Udo, Chemical and structural characterization of As immobilization by nanoparticles of mackinawite (FeS $\mathrm{m}_{\mathrm{m}}$ ), Chem. Geol. 268 (2009) 116-125.

[8] Y.S. Han, A.H. Demond, T.J. Gallegos, K.F. Hayes, Dependence of particle concentration effect on $\mathrm{pH}$ and redox for arsenic removal by FeS-coated sand under anoxic conditions, Chemosphere 134 (2015) 499-503.

[9] X.J. Xie, Y.Q. Liu, K.F. Pi, C.X. Liu, J.X. Li, M.Y. Duan, Y.X. Wang, In situ Fe-sulfide coating for arsenic removal under reducing conditions, J. Hydrol. 534 (2016) 42-49.

[10] H. Guo, D. Stuben, Z. Berner, Adsorption of arsenic(III) and arsenic(V) from groundwater using natural siderite as the adsorbent, J. Colloid Interface Sci. 315 (2007) 47-53.

[11] L.C. Roberts, S.J. Hug, T. Ruettimann, M.M. Billash, A.W. Khan, M.T. Rahman, Arsenic removal with iron(II) and iron(III) in waters with high silicate and phosphate concentrations, Environ. Sci. Technol. 38 (2004) 307-315.

[12] J.A. Cherry, A.U. Shaikh, D.E. Tallman, R.V.J. Nicholson, Arsenic species as an indicator of redox conditions in groundwater, J. Hydrol. 43 (1979) 373-392.

[13] E.A. Rochette, B.C. Bostick, G.C. Li, S. Fendorf, Kinetics of arsenate reduction by dissolved sulfide, Environ. Sci. Technol. 34 (2000) 4714-4720.

[14] S. Stauder, B. Raue, F. Sacher, Thioarsenates in sulfidic waters, Environ. Sci. Technol. 39 (2005) 5933-5939.

[15] L.E. Eary, The solubility of amorphous As2S3 from 25 to $90^{\circ} \mathrm{C}$, Geochim. Cosmochim. Acta 56 (1992) 2267-2280.

[16] G.R. Helz, J.A. Tossell, Thermodynamic model for arsenic speciation in sulfidic waters: a novel use of ab initio computations, Geochim. Cosmochim. Acta 72 (2008) 4457-4468.

[17] G.S. Zhang, J.H. Qu, H.J. Liu, R.P. Liu, R.C. Wu, Preparation and evaluation of a novel Fe-Mn binary oxide adsorbent for effective arsenite removal, Water Res. 41 (2007) 1921-1928.

[18] L.E. Jenny, D.C. Sean, M.G. Christina, M.K. Kevin, R.Y. Andrea, A.C. Patricia, A.C Joseph, T.C. John, Complementary molecular and elemental detection of speciated thioarsenicals using ESI-MS in combination with a xenon-based collision-cell ICP-MS with application to fortified NIST freeze-dried urine, Anal. Bioanal. Chem. 390 (2008) 1731-1737.

[19] S. Elke, P.F. Britta, Thioarsenate formation upon dissolution of orpiment and arsenopyrite, Chemosphere 89 (2012) 1390-1398.

[20] Y.S. Han, H.Y. Jeong, A.H. Demond, K.F. Hayes, X-ray absorption and photoelectron spectroscopic study of the association of As(III) with nanoparticulate FeS and FeS-coated sand, Water Res. 45 (2011) 5727-5735.

[21] C. Claire, L.W. Paul, J.V. David, Cleaved natural orpiment $\left(\mathrm{As}_{2} \mathrm{~S}_{3}\right)$ by XPS, Surf. Sci. Spectra 13 (2006) 100-108.

[22] W.R. Salaneck, R. Zallen, Surface charging effects on valence band spectra in Xray photoemission crystalline and amorphous $\mathrm{As}_{2} \mathrm{~S}_{3}$, Solid State Commun. 20 (1976) 793-797.

[23] H.Y. Hu, Y. Fang, H. Liu, R. Yu, G.Q. Luo, W.Q. Liu, A.J. Li, H. Yao, The fate of sulfur during rapid pyrolysis of scrap tires, Chemosphere 97 (2014) 102-107.

[24] M.A. Hampton, C. Plackowski, A.V. Nguyen, Physical and chemical analysis of elemental sulfur formation during galena surface oxidation, Langmuir 27 (2011) 4190-4201. 